\title{
MACHINE TRANSLATION POST-EDITING - CURRENT SITUATION AND THE FUTURE OF TRANSLATOR TRAINING IN BULGARIA
}

\author{
Irina Stoyanova-Georgieva \\ Department of English Studies, \\ Konstantin Preslavsky University of Shumen, Shumen, Bulgaria
}

\begin{abstract}
The current paper is an attempt to analyse the situation on the market for specialised translation services, and more precisely for Machine Translation in Bulgaria. It provides an overview of some of the generic MT systems and analyses the results coming from the translation of two types of text. The aim of the paper is to raise awareness about the results of Neural Machine Translation and to reveal the need for MT post-editing courses.
\end{abstract}

Key words: Neural Machine Translation, specialised translation services, post-editing

\begin{abstract}
About the author: Irina Stoyanova-Georgieva, PhD is a lecturer in the English Studies Department of Konstantin Preslavsky University of Shumen, Bulgaria. She has done a translation traineeship at the European Parliament and has a PhD thesis on the use of intensifiers in letters to the editor in British and Bulgarian newspapers and magazines. Her main interests are in the field of translation studies and translation technologies.
\end{abstract}

e-mail: i.stoyanova-georgieva@shu.bg

ORCID iD: https://orcid.org/0000-0003-4065-4917

\section{Copyright (c) 2021 Irina Stoyanova-Georgieva}

Article history: Received: 25 October 2021; Reviewed: 30 October 2021; Revised: 14 November 2021; Accepted: 15 November 2021; Published: November 2021

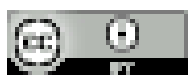

This open access article is published and distributed under a Creative Commons Attribution 4.0 International License.

Citation (APA): Stoyanova-Georgieva, I. (2021). Machine translation post-editing - Current situation and the future of translator training in Bulgaria. Studies in Linguistics, Culture, and FLT, 9(3), 63-75. https:// doi.org/10.46687/AGZJ3808. 


\section{Introduction}

According to a recent study by Rangelov et al. (2021) the market share of the translation business in Bulgaria is worth 45 million leva. Half of its revenue is generated by the top 100 Language Service Providers (LPS). More than twothirds of all of these agencies are located in Sofia and all of them offer written translation services, while the next most popular services are legalisation and consecutive translation. And though written translation, together with consecutive and simultaneous interpretation represent the most conventional and recognisable type of service, it is one particular type of service that is offered by the top three LSPs and only $20 \%$ of the rest of the agencies. It is the fact that they offer specialised translation services which, according to the authors of the study, include editing, revision, use of CAT tools, localisation, subtitling, dubbing, transcreation, language quality control, machine translation, machine translation post-editing, copywriting, etc.

Such a low percentage of supply of translation services, which cannot be described as cutting edge, seems anomalous since the search for better, faster and cheaper solutions has been on the rise even more so after the beginning of the Cold War (Sin-wai, 2015, p. 4). What is more, CAT tools have been the leading tool for translation for more than 20 years now (Zetzsche, 2020, p. 169), audiovisual translation has existed for even longer (Cintas \& Remael, 2021), however, it is MT that has surprised the industry in the recent years. Ever since the appearance of the first translation machine, MT has revolutionised the idea about translation. Consequently, "necessity for Machine-Assisted Translation (MAT) has become obvious in multinational companies, professional societies, in government agencies, in EU etc." (Seljan \& Pavuna, 2006). The recent European Language Industry Survey for 2020, based on 809 responses from 45 counties, further proves that MT is the strongest among all technology trends (ELIS, 2020, p. 48).

The practicalities explaining the discrepancy between the range of translation services provided in most European LSPs (ELIS, 2020) and those offered in Bulgaria can be imparted partly to the state of economy and the country's low position in world export. To be more specific, according to the Bulgarian Industrial Association, in 2020 Bulgaria ranked 58th, right after Nigeria and Lithuania (Bulgarian Industrial Association, 2021, July 27). But limiting the supply of such services only to the economic factors (additional monthly/annual costs for CAT tools, MT engines' subscription1 fees and long training periods

1. Google Translate's AutoML translation pricing is based on the training required (in hours) and the number of characters sent for translation and is taxed per monthly usage. The service is free for the first 500k characters, which according to the information cost about $\$ 40$, and anything above is billed according to a scheme. For text translation (TXT, HTML, and XLSX formats), the pricing varies according to the monthly usage 
(Wu et al., 2016, p. 1), small market and obviously low demand) means to overlook the rest of the aspects. These reasons, namely, the low awareness of the results of MT engines after the introduction of Neural MT in 2016, the wariness of education institutions, and the less flexible, and adaptable university curricula in Bulgaria present an equally strong argument against the establishment of strong specialised translation services market. However, it is the universities that should bridge the gap between the language professionals and the business, and its needs. The first step to be taken, in order to overcome difficulties and to prepare professionals for their future, is to be done by the universities.

\section{Then and now}

It is hardly a surprise that with the establishment of the Internet the market for translations has grown rapidly. This growth has caused a shift in the industry and prompted companies to search avidly for tools that can increase productivity but maintain the high quality of human translation. This quest included not only translation memory tools but also experimentation with Machine Translation (MT). This can be seen in the data presented in the study of Loffler-Laurian as cited in Seljan and Pavuna (2006). According to it, in 1990s, human translators in Europe and the USA together, generated 300 million pages, while MT was

from $\$ 80$ per million characters for the range between $500 \mathrm{k}$ and $250 \mathrm{M}$ characters to $\$ 30$ per million for 4 billion characters and more and for document translation it is a fixed sum of $\$ 0.25$ per page no matter the characters (Google Cloud, 2021).

DeepL - Starter ( $€ 5.99$ per user per month, billed annually), Advanced ( $€ 19.99$, per user per month, billed annually), Ultimate ( $€ 39.99$, per user per month, billed annually) (DeepL Pro, 2021)

Microsoft Translate offers for free 2M characters (standard translation and custom training) per month and while its prices vary according to the type of translation, standard or custom, with $\$ 10$ per million characters for the first to $\$ 40$ per million for the second, there are various other volume discounts based on the type of translation and the volume (Microsoft Azure, 2021).

Systran Translate also offers free MT service but its pro version costs $€ 4.99$ for individual or self-employed professionals (Lite) for 150 pages (Text, Word, Excel, Powerpoint), $€ 13.99$ for small businesses with international ambitions (Plus version) which includes the Lite version file formats and pdfs for 600 pages per user per month. Unfortunately, it is only the Premium version that includes CAT/TMS tools connectors + Translation Memories and its price is $€ 31.99$ (Systran Translate, 2021).

Yandex Translate API pricing is once again based on the number of characters starting with $\$ 15$ for less than 50 million and going to $\$ 6$ for great volumes (from 500 million to 1 billion) (Yandex Translate, 2021).

Amazon Translate's pricing scheme is relatively the same. Users can translate up to $2 \mathrm{M}$ characters monthly for 12 months, but are then billed monthly for the characters sent to the engine ( $\$ 15$ per million characters) or $\$ 60.00$ per million characters (monthly payment) for Active Custom Translation that uses parallel data to customize the machine translated output (Amazon Translate, 2021). 
responsible for 2.5 million pages only. In Japan the situation was roughly the same with 150 million pages' output for human translators and 3.5 million pages for MT. Calculations show that back then machine-generated translations represented only about $1 \%$ of the overall production. Less than ten years later "in 2000 a total of 546.248 pages were machine translated for needs of EU" (Seljan \& Pavuna, 2006, p. 470). And for the period between 2012 and 2017 the overall quantity of translations done by the Directorate-General for Translation (DGT) of the EU increased with several hundred thousand from slightly over 1.7 million in 2012 to more than 2.2 million in 2014 and 2016 (Krasteva, 2018, March 20). The introduction of Google's Neural Machine Translation (NMT) in 2016 opened a new door for the machines in the process of translation. This state-of-the-art technology had "the potential of addressing many shortcomings of traditional MT systems" (Wu et al., 2016, p. 1). The results did not fall short of the expectations and in 2018 Google CEO Sundar Pichai announced, as cited in Business Insider, that the company app translated 143 billion words daily (Wolverton, 2018, July 24). Naturally, Google's example was followed by many and today NMT is used in DeepL, Systran Translate, Microsoft Translator, Yandex, Amazon Translate, etc. As might be expected, this has led to an increase in the number of people and companies relying on it.

The global pandemic of 2020 has given further impetus to the online trading and ecommerce which has deepened the need for faster or even instant translations. The reverberations can be detected in the trends for the translation business. According to the European Language Industry Survey for 2020 MT and postediting were the strongest trend for all respondents - LSPs, independent language professionals, training institutes, translation departments, and language buyers (ELIS, 2020, p. 67).

Taking into consideration the abovementioned data it is interesting to discuss the answer of the LSPs and translation departments in education institutions. According to the ELIS, MT is on top: $66 \%$ of the agencies and $44 \%$ of the in-house translation teams expect to invest in it in 2020 (ELIS, 2020, p. 50). Regardless of these results, departments are still oriented toward translation memory technologies (51\%) and only $44 \%$ are planning to invest in MT. These upshots prove that the education institutions are somehow overlooking the progress done by MT and the obvious indispensability of the technology for the future generation of translators. Despite the willingness of translation providers to modernise their business, the study reveals yet another trend - TM is still the most popular tool and the majority of independent professionals use MT only occasionally, and it takes the $5^{\text {th }}$ place after translation/content Mgt tools, term management tools, TMs, and OCR tools (ELIS, 2020, p. 51). Among those who listed MT usage DeepL was the most preferred tool followed by Google and Microsoft Azure. Based on this, the current study analyses the results of these three, adding Yandex Translate and Systran to complete the list. 
The Bulgarian higher education institutions do not differ from their EU colleagues in their approach to translation technology. Despite the fact that work on MT in Bulgaria started as early as 1964, when the country was among the first 31 countries to be "engaged in the research and development of MT" (Sin-wai, 2015, p. 26), the current situation differs. Today most universities offer courses in translation memory tools, but for the prevalent part of the institutions this modernisation of the curriculum happened only in the last 10 years. Further to this, courses in MT are still a rarity which, given the trends and the abovementioned statistical information, is an oversight. An easily remedied one, though, as the market offers free access to high quality MT tools. Based on the results of other countries, such a development can create a positive attitude towards translation technology (Seljan \& Pavuna, 2006, p. 274) and can allow future translators to assess their benefits and drawbacks.

\section{Methods of analysis}

Though in the past "MT was primarily used to get a rough translation of a text", Google "MT neural revolution" in 2016 significantly improved the quality, consistency, and productivity of the system (Giulianelli, 2021, Sept 24). It is a common notion that there is no flawless tool that can translate all types of content delivering high quality results and each tool has its advantages and disadvantages.

This motivates the selection of several MT systems (Systran Translate, DeepL, Yandex Translate, Microsoft Translator, Google Translate, and eTranslation), which will be compared on the basis of their technological features and output for the language combination English - Bulgarian. The selected texts are an excerpt from technical documentation (car manual) and a meeting document of the European Parliament (minutes), both about 2000 characters long.

The methodology applied in the paper differs from the standard evaluation metrics, used in such cases. As Federmann states, "there exists a plethora of different automatic evaluation metrics for MT, their output in terms of scores, distances, etc. quite often is neither transparent to translators nor shows good correlation with manual evaluation by human experts" (Federmann, 2011). In line with Federman's ideas, the current paper relies on assessment of the postediting effort needed in order to turn raw MT output into publishable content or full post-editing, according to the ISO Standard (International Organization for Standardization [ISO], 2017).

The aim is not only to show the state of general MT for Bulgarian, but to raise awareness of the output which can be used in MT and post-editing courses. 


\section{Short analysis of several MT tools and their output}

Systran Translate is the oldest industrial MT system, founded in 1968 (Cardey, 2015, p. 286). It was the principal MT software for the European Commission from 1976 (Petris, 2001; Seljan \& Pavuna, 2006, p. 472) until 2003 (Court of Justice, 2010). Back then the quality of the translated text depended "greatly on the similarity of source and target languages, restricted domain, writing style and rich dictionaries" (Seljan \& Pavuna, 2006, p. 472). Currently, the system offers translation in more than 55 languages and 140 language combinations. Some of the key characteristics, advertised on its website, are that it translates documents preserving the initial layout, uses client's dictionaries and TMs, and gives access to industry-specific translation engines (Systran Translate, 2021). Guilianelli defines Systran as "hybrid translation, combining rule-based and statistical MT to guarantee predictable and consistent translations, compliance with corporate terminology, out-of-domain usability, high performance, and the possibility to learn from existing monolingual and multilingual corpora with few customization costs" (2021, September 24).

DeepL advertises its product DeepL Translate as "the world's best machine translation" stating that the company's networks consistently outperform other translation systems like Google Translate, Amazon Translate, and Microsoft Translator (DeepL, 2021). The company introduced Bulgarian as supported language on 17 March 2021 (DeepL, 2021). But because it 'was launched in 2017 to further develop Linguee, the world's biggest database of human translations (Giulianelli, 2021, Sept. 24) and it was trained with its data, the results should very well surpass the expectations despite the short period of exploitation. The system offers translation of whole documents by its drag and drop function, and even incorporation of specific terminology in the translation (Giulianelli, 2021, Sept. 24).

High quality NMT for 90+ languages, fast localisation services (translation of websites, product titles, descriptions and specifications), and promotion of social and communication translation is what Yandex Translate offers to its clients (Yandex Translate, 2021).

Microsoft Translator also utilizes the newest NMT; it is available for more than 100 languages, including Bulgarian. Today it is one of the most widely used MT engines (Sin-Wai, 2015) and many companies rely on its services for their localisation projects. A peculiar feature of Microsoft Translator is the translation of a large variety of widely used phrases accessible through a list of categories. Its popularity among users is set down by its integration in almost all of Microsoft products like Bing and Teams.

Google Translate can be deemed by far as the most popular MT system. It started as a statistical MT in 2006 when it learned from books, organisations, 
the Internet and harvested texts and searched for patterns between target texts and source texts (Lotz \& Rensburg, 2014, p. 235). But it was its introduction of the first NMT system in 2016 that changed the market for translations for all of us. Shortly after its launch, Wu et al. stated that the "GNMT system approaches the accuracy achieved by average bilingual human translator" (Wu et al., 2016, p. 20) and that the "system delivers roughly a $60 \%$ reduction in translation errors on several popular language pairs" (Wu et al., 2016, p. 20). Bulgarian was in the last of the predesigned groups to receive NMT and the transition from statistical to NMT was done in late 2017 but the results were just as accurate.

Currently the system offers free service for more than 100 languages with just a monthly limitation, and just like DeepL it can translate entire documents with the drag and drop function (Giulianelli, 2021, Sept. 24).

eTranslation is the heir of Mt@EC. MT for the European Commission has a long standing tradition. Starting with the use of Systran in 1976, the EC developed its own engine Mt@EC which was launched in June 2013 (Foti, 2018, Oct. 24) and followed by the more sophisticated NMT of eTranslation in November 2017 (Foti, 2018, Oct. 24). When it was launched, eTranslation was intended for individuals in public administration, system suppliers, and digital service infrastructures (Foti, 2018, Oct 24). At present, it is also available for small and medium-sized enterprises and university language faculties (European Commission, 2021). The service is also available through an API which allows its integration into a tool. And though it is free of charge, the system requires an account from the user. The Commission warns users that eTranslation "translates from and into any official EU language" but "works best with texts on EU-related matters" and similarly to custom MT engines it guarantees that the processed data is protected from outsiders (European Commission, 2021).

Analysis of the post-editing effort required for publishable quality

The analysis of the texts revealed both the strengths and the deficiencies of MT output. Some of these were examples of the evolution of NMT as a reliable tool, while others still reminded of the results of Statistical MT before 2016. But while the output from all of the examined MT systems showed various kinds of errors, wrong words, missing or unnecessary commas, unnecessary or missing capitalisations, faulty sentence structures, shifts in verb tense, etc., a considerable number of the sentences translated with some of the MT systems, required little or no post-editing at all:

Official document (DROI_PV(2019)0710_1): Maria Arena consented to the nomination, confirmed that she had filled in the declaration of financial interests and the declaration relating to the Code of appropriate behaviour, and was elected Chair by acclamation. 
Google Translate: Мария Арена даде съгласието си за номинацията, потвърди, че е попълнила декларацията за финансови интереси и декларацията, свързана с Кодекса за подходящо поведение, и беше избрана за председател чрез акламация

Insignia Owner's Manual EN: licensed to service gas vehicles.

Systran Translate: лицензиран да обслужва газови превозни средства.

Insignia Owner's Manual EN: This Owner's Manual depicts left- hand drive vehicles.

eTranslate: Наръчника на собственика изобразява превозни средства с ляво задвижване. Операцията е подобна за превозните средства с дясно кормилно управление.

Official document (DROI_PV(2019)0710_1): Isabel Santos, on behalf of the S\&D Group, proposed Maria Arena as Chair

DeepL: Isabel Santos, от името на групата S\&D, предложи Maria Arena за председател.

Official document (DROI_PV(2019)0710_1): Phil Bennion, on behalf of Renew Europe, proposed Irina Von Wiese as first Vice-Chair. Irina Von Wiese consented to the nomination, confirmed that she had filled in the declaration of financial interests and the declaration relating to the Code of appropriate behaviour, and was elected first Vice-Chair by acclamation.

Systran: От името на Renew Europe Фил Бениън предложи Irina Von Wiese за първи заместник-председател. Irina Von Wiese се съгласи да номинира, потвърждава, че е попълнила декларацията за финансовите интереси и декларацията, свързана с Кодекса за подходящо поведение, и е избрана за първи заместник-председател чрез обвинението.

As was stated, the performance of the tools varies according to the language combination and content of the translated text, which can explain the results for the first text type, a representative of technical texts. Starting with the inconsistencies, one of the first things that a post-editor notes is that the text translated by Systran lacks the necessary intervals. As a result, two or even more words are merged into one single unit which requires significant postediting effort. Another weakness spotted in the results of all but one of the chosen MT systems is that they fail to recognise the need for polite pronouns which are essential for official communication in Bulgarian. eTranslation was the only tool that used polite pronouns though not everywhere. However, it has to be taken into consideration that even the official translation of the manual lacks some of the polite pronouns:

Microsoft Translator: Уверете се, че вашите пътници са наясно с възможния риск от злополука и нараняване, които могат да възникнат в резултат на неправилна употреба на превозното средство. 
eTranslator: Моля, въведете данните на Вашето превозно средство на предишната страница, за да ги поддържате лесно достъпни.

Official translation of the user manual of Insignia for Bulgaria (Official Translation): Пренебрегването на описанието, дадено в това ръководство, може да повлияе върху вашата гаранция.

It is important to mention another specificity which can come as a surprise to the novice post-editor, namely the localisation of the name of the make Vauxhall with its equivalent Opel, sold in EU countries. And though the localisation is not consistent, this signals the sophistication of the MT and the best results come from Google.

Google: Когато това ръководство за собственика се отнася за посещение в сервиз, ние препоръчваме вашия оторизиран сервиз на Opel. За автомобили на газ препоръчваме оторизиран сервиз на Opel, лицензиран за обслужване на автомобили на газ.

Всички оторизирани сервизи на Opel предоставят първокласно обслужване на разумни цени. Опитни механици, обучени от Vauxhall, работят според специфични инструкции на Opel.

The review shows that the strongest results, which need minimal or no postediting, for this type of text come from Google translate, DeepL, and Microsoft Translator, while the output of Systran Translate is the weakest, requiring much attention and alteration, as the translated text is sometimes not coherent.

Insignia Owner's Manual EN: This Owner's Manual provides you with all the necessary information to enable you to drive your vehicle safely and efficiently.

Official Translation: Настоящото ръководство за експлоатация Ви предоставя цялата необходима информация за да можете да карате автомобила си правилно и сигурно.

Google Translate: Това ръководство на собственика ви предоставя цялата необходима информация, за да ви позволи да управлявате автомобила си безопасно и ефективно.

DeepL: Настоящото ръководство за експлоатация ви предоставя цялата необходима информация, за да можете да управлявате автомобила си безопасно и ефективно.

Systran Translate: Наръчникът на този собственик випредоставя цялата необходимаинформация, за да можете да управлявате превозното си средствобезопасно и ефективно.

Based on the results for this type of text and despite the disclaimer on its homepage eTranslator is the system which surprises the researcher most as its output resembles very much the official translation of the manual and those of Google and DeepL: 
Insignia Owner's Manual EN: You must always comply with the specific laws and regulations of the country that you are in.

Official translation: Вие винаги трябва да спазвате конкретните закони и правила на страната, в която се намирате.

Google Translate: Винаги трябва да спазвате специфичните закони и разпоредби на държавата, в която се намирате.

DeepL: Винаги трябва да спазвате специфичните закони и разпоредби на страната, в която се намирате.

eTranslator: Винаги трябва да спазвате конкретните закони и разпоредби на страната, в която се намирате.

Analysing the results for the second excerpt, researchers once again encounter certain tendencies. And though there were inconsistencies in the terminology of the translations of the first text they were minor. All but one of the examined TM systems display terminological issues.

Insignia Owner's Manual EN: Minutes Systran: Минути

Official translation: Протокол

Microsoft Translator: Минути

Google translate: Минути

Yandex Translate: Минута

DeepL: Методика

eTranslator provided the highest quality results and used consistent terminology but despite the fact that the engine is trained with similar and identical texts it still displays minor diversions in the vocabulary, using words that are not typical for this type of content:

Official document (DROI_PV(2019)0710_1): Charles Goerens welcomed the Members and noted that there was a quorum. He informed that Silvia Sardone ID) replaces Lars Berg (ID).

Official BG translation: Шарл Гьоренс приветства членовете на ЕП и установи, че е постигнат кворум. Той съобщи, че Силвия Сардоне (ID) замества Ларс Берг (ID).

eTranslator: Шарл Гьоренс приветства членовете на ЕП и отбеляза, че е налице кворум. Той информира, че Silvia Sardone (ID) заменя Lars Berg (ID).

Nonetheless, eTranslator was the best performing engine in the group. Systran's performance once again was deemed as low quality as the system displayed grammatical, punctuation, and word order issues apart from the lexical ones. Its output demands lots of effort to achieve the standards for full post-editing.

Other common problems for all of the systems included unnecessary punctuation marks, translation of untranslatables: PPE, S\&D, ID, Verts/ALE, and use of inconsistent tenses. 
To summarise, the results demonstrate once again that the output from different MT tools varies from content to content. However, it was observed that Google Translate, DeepL, and Microsoft Translator provided better quality, followed closely by Yandex Translate and eTranslate. Systran Translate translations, unfortunately, required too much post-editing efforts. An attempt may be made to explain this outcome considering the greater popularity of Google and Microsoft Translate in Bulgaria and the low demand for other tools like Systran Translate.

Despite this, it should be noted, as Petrits states, that "machine translation is not aimed at replacing human translators... It is simply a complementary, surprisingly fast tool, that can rescue translators or administrators from some dull work" (Petrits, 2001, p. 29).

\section{Conclusion}

The study carried out by Rangelov et al. (2021) gives us an insight into the specificities of the LSPs in Bulgaria. However, it also allows us to speculate on the reason why it is the top three companies that offer specialised translation services or perhaps why these three companies are at the top of the ranking. There are considerable changes going on with the business in the last few years, namely, global demand for localisation of products, faster translation services and growing online trading and ecommerce, and they call for an alteration in the translation services as well as in their teaching.

\section{References:}

Amazon Translate. (2021). Amazon Translate pricing. Retrieved November 13, 2021, from https://aws.amazon.com/translate/pricing.

Bulgarian Industrial Association. (2021). Myastoto na Bulgarya v svetovniya iznos prez 2020 g. Retrieved November 13, 2021, from https://www.bia-bg. com/analyses/view/28857.

Cardey, S. (2015). Translation technology in France. In Ch. Sin-wai (Ed.), The Routledge Encyclopedia of Translation Technology (pp. 279-291). London \& New York: Routledge, Taylor \& Francis Group.

Cintas, J. D., \& Remael, A. (2021). Subtitling: Concepts and Practices. Routledge.

Court of Justice. (2010 December 16). The General Court orders the Commission to pay Systran liquidated damages of $€ 12001000$ [Press release]. Retrieved November 13, 2021, from https://ec.europa.eu/commission/presscorner/ detail/en/CJE_10_123.

DeepL Translator. (2021). Retrieved November 13, 2021, from https://www. deepl.com/translator. 
eepL Translator. (2021). DeepL Pro-fast, accurate, and secure translations. Retrieved November 13, 2021, from https://www.deepl.com/pro.

European Commission. (2021). Machine translation for public administrations - eTranslation. European Commission. Retrieved November 13, 2021, from https://ec.europa.eu/info/resources-partners/machine-translation-publicadministrations-etranslation_en.

European Union Association of Translation Companies. (2021). European language industry survey 2020: Before \& after Covid-19 [Data set]. EUATC. Retrieved November 13, 2021, from https://ec.europa.eu/info/sites/default/ files/2020_language_industry_survey_report.pdf.

Federmann, C. (2011, March 3-4). How can we measure machine translation quality? [Paper presentation]. Tralogy. France. Retrieved November 13, 2021, from http://lodel.irevues.inist.fr/tralogy/index.php?id=76\&format=print.

Foti, M. (2018, October 24). The CEF eTranslation platform@work [PowerPoint Slides]. European Language Resource Coordination, European Commission.

Giulianelli, D. (2021, September 24). 5 Machine Translation Tools to Try (and Use) Now. Memsource. Retrieved November 13, 2021, from https://www. memsource.com $/ \mathrm{blog} / \mathrm{machine}$-translation-tools.

Google. (2021). AutoML Translation pricing. Google. Retrieved November 13, 2021, from https://cloud.google.com/translate/automl/pricing.

International Organization for Standardization. (2017). Post-editing of machine translation output (ISO 18587:2017). Retrieved November 13, 2021, from https://www.iso.org/standard/62970.html.

Krasteva, D. (2018, March 20). Da prevezhdash za Evropeiskiya saiyz [PowerPoint Slides]. European Commission.

Lotz, S., \& Rensburg, A. (2014). Translation technology explored: Has a threeyear maturation period done Google Translate any good? Stellenbosch Papers in Linguistics Plus, 43(1), 235-259. https://doi: 10.5842/43-0-205.

Microsoft Azure. (2021). Translator pricing. Retrieved November 13, 2021, from https://azure.microsoft.com/en-us/pricing/details/cognitive-services/ translator/\#pricing.

Petrits, A. (2001). EC Systran: The Commission's Machine Translation system. Directorate of Resources and Language Support, Translation Service, European Commission. Retrieved November 13, 2021, from https:// aclanthology.org/www.mt-archive.info/00/Petrits-2001.pdf.

Rangelov, S., Rangelova, N., Klisurova, N., Georgieva, Dzh., Dormush, S., Bozova, S., \& Tsvetkova, T. (2021). Top 100 Prevodacheski agentsii v Bulgaria [Data set]. OLTRANS. Retrieved November 13, 2021, from https:// www.top100pab.eu. 
Seljan, S., \& Pavuna, D. (2006). Why Machine-Assisted Translation (MAT) Tools for Croatian? Proceedings of 28th International Information Technology Interfaces Conference - ITI. 469-475. Retrieved November 13, 2021, from https://www.researchgate.net/publication/224651245 Why_machine-assisted_translation_MAT_tools_for_Croatian.

Sin-wai, Chan. (2015). The development of translation technology: 1967-2013. In Ch. Sin-wai (Ed.), The Routledge encyclopedia of Translation Technology (pp. 3 - 31). Routledge.

Systran. (n.d.). Systran translate. Retrieved November 13, 2021, from https:// translate.systran.net.

Systran Translate. (2021). Professional translation plans \& pricing SYSTRAN Translate PRO. Retrieved November 13, 2021, from https://www. systransoft.com/translation-products/pro.

Translate API - yandex translate. Yandex. Cloud. (n.d.). Retrieved November 13, 2021, from https://cloud.yandex.com/en/services/translate.

Wolverton, T. (2018, July 24). Google CEO Sundar Pichai revealed a jaw dropping-fact about its translation app that shows how much money is still sitting on the table. The Business Insider. Retrieved November 13, 2021, from https://www.businessinsider.com/sundar-pichai-google-translate-143-billionwords-daily-2018-7? $\mathrm{r}=\mathrm{US} \& I \mathrm{R}=\mathrm{T}$.

Wu, Y., Schuster, M., Chen, Z., Le, Q., Norouzi, M., Macherey, W., Krikun, M., Cao, Y., Gao, Q., Macherey, K., Klingner, J., Shah, A., Johnson, M., Liu, X., Kaiser, Ł., Gouws, S., Kato, Y., Kudo, T., Kazawa, H., Stevens, K., Kurian, G., Patil, N., Wang, W., Young, C., Smith, J., Riesa, J., Rudnick, A., Vinyals, O., Corrado, G., Hughes, M., \& Dean, J. (2016). Google's Neural Machine Translation System: Bridging the Gap between Human and Machine Translation. Retrieved November 13, 2021, from https://arxiv.org/ abs/1609.08144.

Žd'árek, D. (2021, Oct. 12). Machines That Think: The Rise of Neural Machine Translation. Memsource. https://www.memsource.com/blog/neuralmachine-translation.

Zetzsche, J. (2020). Freelance translators' perspectives. In M. O’Hagan (Ed.), Routledge Handbooks in Translation and Interpreting Studies (pp. 166 - 182). Routledge. 